\section{Standardverk om kolorektal kirurgi}

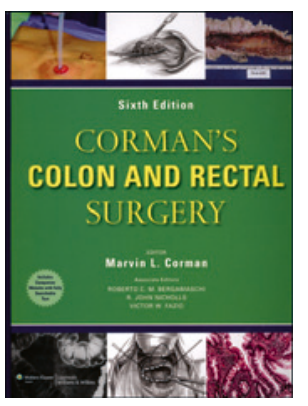

Marvin L. Corman, red.

Corman's colon and rectal surgery

6. utg. 1564 s, tab, ill. Philadelphia,

PA: Lippincott Williams \& Wilkins, 2012.

Pris USD 369

ISBN 978-1-4511-1114-9

I forordet skriver Corman at det $\mathrm{i}$ boken ikke finnes hellige sannheter eller diktater. De 34 kapitlene reflekterer derfor de 37 medforfatternes personlige meninger, kunnskaper og erfaring, selv om man nok kan merke Cormans hånd i det meste. Han er eneforfatter eller medforfatter av 11 kapitler. Med seg har han tre medredaktører: Roberto C. M. Bergamaschi, R. John Nicholls og Victor W. Fazio. Av de øvrige forfatterne er alle unntatt fire fra USA, hvilket nok preger utgivelsen noe. Den dekker alle områder innen kolorektal kirurgi. Kapitlene avsluttes gjerne med en generell kommentar og/eller forfatterens mening.

Utformingen er tradisjonell - innledningsvis er det kapitler om anatomi, embryologi og colons fysiologi, etterfulgt av kapitler om spesifikke kirurgiske temaer. Det er rikelig med illustrasjoner fremragende, instruktive bilder med trinnvis fremstilling av kirurgiske prosedyrer.

I tråd med Cormans interesse for medisinsk historie er korte vignetter med bilder av kirurger og vitenskapsmenn som har hatt betydning for kolorektal kirurgi innsprengt i teksten, noe som nok mange vil verdsette.

Kunnskap om anorektal fysiologi er vesentlig for alle som utfører kolorektal kirurgi, og i et kapittel om oppbygging av et rektalfysiologisk laboratorium beskrives samtlige tilgjengelige tester med fortolkning.

Kolorektale manifestasjoner av aids (hiv), et viktig og ofte forsømt område, er viet et eget kapittel.

I den utmerkede seksjonen om laparoskopisk tykktarms- og endetarmskirurgi beskrives samtlige aktuelle inngrep detaljert - oppsett, utføring, komplikasjoner, fordeler og ulemper, ledsaget av instruktive bilder og figurer. Særskilt oppmerksomhet er viet kikkhullskirurgi for tykktarms- og endetermskreft, inkludert robotkirurgi. Dette er betimelig, ettersom man må forvente at kikkhullskirurgi ved disse kreftformene vil bli vesentlig mer vanlig i fremtiden. I det omfangsrike avsnittet om fekal inkontinens behandles årsakssammenhenger og behandlingsalternativer på en eksemplarisk måte. Kapitlet er en tilgang for alle som vil skaffe seg en oversikt over dette intrikate problemkomplekset. Mye plass er viet beskrivelse og kritisk evaluering av ulike former for nervestimulering for behandling av avføringsinkontinens, et svært aktuelt tema.

I kapitlet om endetarmskreft er det brukt mye spalteplass på betydningen av fascieforholdene for radikal operasjon, og det beskrives hvordan anatomien historisk er blitt kartlagt. Forfatterens egen teknikk er nøye beskrevet, med utmerkede illustrasjoner. Ved rectumamputasjon for cancer bruker han konvensjonell teknikk, som beskrevet av Miles. I de senere år er det blitt hevdet at denne teknikken ikke er omfattende nok, og ekstralevatorisk reseksjon anbefales av noen. Forfatteren mener at konvensjonell teknikk, dersom den er korrekt utført, gir like gode resultater og argumenterer for det.

Generelt belyses hvert enkelt tema ut fra patofysiologiske og kliniske aspekter, og ulike behandlingsalternativer vurderes kritisk. Eksempler er de velskrevne og omfangsrike kapitlene om kirurgisk behandling av ulcerøs kolitt og Crohns sykdom.

Corman's colon and rectal surgery er nyttig for alle kirurger som praktiserer tykktarms- og endetarmskirurgi, etablerte så vel som dem under utdanning. Særskilt vil jeg fremheve de fremragende og detaljerte illustrasjonene. Dette er en utmerket referansebok, ikke minst på grunn av det store antall referanser som ledsager hvert kapittel. Positivt er det at det medfølger en personlig kode som gir tilgang til innholdet online, fullt søkbart.

\author{
Helge Elliot Myrvold \\ Det medisinske fakultet \\ Institutt for kreftforskning og molekylær medisin \\ Norges teknisk-naturvitenskapelige universitet
}

Oppgitte interessekonflikter: Anmelder oppgir at han er medforfatter på noen artikler publisert av Bergamaschi sent på 1990-tallet, men at dette forhold ikke har hatt betydning for hans anmeldelse.

\section{Godt skrevet om ledelse av helsetjenester}

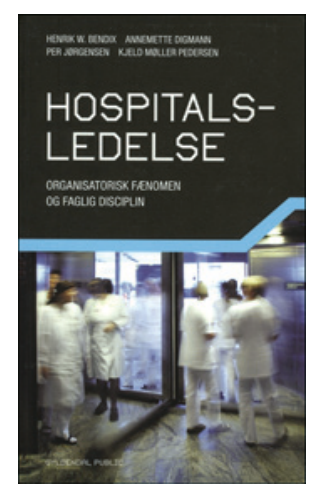

Henrik W. Bendix, Annemette Digmann, Per Jørgensen, Kjeld Møller Pedersen Hospitalsledelse Oganisatorisk fænomen og faglig disciplin. 460 s, tab, ill. København: Gyldendal Business, 2012. Pris DKK 425 ISBN 978-87-02-12956-4

Jeg har lest en god bok. Fire rutinerte personer innen ledelse og helsetjenesteledelse av har satt sammen de viktigste problemstillingene omkring ledelse av helsetjenester. I 18 kapitler diskuterer forfatterne de aller fleste av de forhold som påvirker, preger og beskriver dette området. Det er tillegg et omfattende litteraturregister.

Her beskrives generell ledelse, organisatoriske prinsipper og styringsmekanikk. Ledelsesmodeller og organisatoriske løsninger diskuteres opp mot pasientforløp i et svært leseverdig kapittel, De nye ledelsesmodeller.

Et helt hovedkapittel i boken (kapittel 3: Ledelse af fagprofessioner) omhandler makt og maktspill i kompetanseorganisasjoner igjen meget leseverdig, gjenkjennbart. Styring av de fire «arketyper» av medarbeidere problematiseres - «primadonnaen», «prestasjonstripperen», «pragmatikeren» og «lønnsmottakeren».

Kapittel 8 og kapittel 9 omhandler det personlige lederskap og hvem som egentlig styrer. Her synes jeg forfatterne viser stor innsikt i hva helsetjenesteledelse innebærer og hvordan det foregår. Kapittel 9, Hvem bestemmer hva i hospitalet?, er meget velskrevet. Det er også et omfattende kapittel om ledelsesforskning om helsetjenesten.

Jeg vil avslutningsvis kommentere det siste kapitlet om fremtidens utfordringer i tjenesten og dermed ledelsen av den. Her beskrives gjenkjennbare scenarioer, utfordringsområder og mange mulige konflikter og dermed utfordringer - igjen meget leseverdig.

Etter mange år som leder i helsevesenet er det lenge siden jeg har lest noe som har vært så verdifullt for meg. Hospitalsledelse kan jeg anbefale på det varmeste til alle ledere og til dem som har tenkt å bli det.

\section{Stener Kvinnsland}

Helse Bergen 